\title{
Frost hardening in white cedar container seedlings exposed to intermittent short days and cold temperatures
}

\author{
by S.J. Colombo ${ }^{1}$ and E.M. Raitanen ${ }^{2}$
}

\begin{abstract}
Shoot frost hardiness development in white cedar (Thuja occidentalis L.) container seedlings in response to intermittent short days (4 days per week) and warm (not less than $15^{\circ} \mathrm{C}$ ) or cool $\left(10 / 5^{\circ} \mathrm{C}\right.$, day/night) temperatures was assessed using the diffusate-electrical conductivity technique. A slight increase in frost hardiness was found within 2 weeks of the start of warm, short days. Frost hardiness increased linearly with time under warm, short days from week 7 to week 14 , with seedlings being resistant to damage at $-10^{\circ} \mathrm{C}$ on week 14 . Approximately onequarter of the seedlings developed brown-green foliage colour after 5 weeks of warm, short day treatment. These seedlings were significantly more frost hardy than the remainder of the seedlings which had dark green foliage. Seedlings exposed to warm, intermittent short days for 13 weeks and then to cool continuous short days for a further 6 weeks became hardy to $-20^{\circ} \mathrm{C}$, while seedlings exposed to warm, intermittent short days only for the full 19 week period did not harden to the $-20^{\circ} \mathrm{C}$ level.
\end{abstract}

Key words: Thuja, daylength, photoperiod

\section{Résumé}

Le développement de la résistance au froid de la pousse terminale de semis de cèdre de l'Est (Thuja occidentalis L.) produits en récipients, à la suite d'une alternance de jours courts (4 jours par semaine) et de températures chaudes (pas de température inférieure à $15^{\circ} \mathrm{C}$ ) ou froides (de 5 à $10^{\circ} \mathrm{C}$, jour et nuit) a été évalué en utilisant la technique de conductivité de l'électricité diffuse. Une légère augmentation de la résistance au froid a été notée dès les deux premières semaines à jours courts et chauds. La résistance au froid s'est accrue de façon linéaire en fonction du temps au cours de la septième à la quatorzième semaine à jours courts et chauds, et les semis sont devenus résistants à des dégats provoqués par une température de $-10^{\circ} \mathrm{C}$ au cours de la quatorzième semaine. Près du quart des semis ont produit un feuillage de couleur brunvert après 5 semaines de traitement de jours courts et chauds. Ces semis étaient significativement plus résistants au froid que les autres semis ayant un feuillage vert foncé. Les semis traités selon des jours courts et chauds alternatifs pendant treize semaines et par la suite selon des jours courts et froids en continu pendant six semaines ont résisté à une température de $-20^{\circ} \mathrm{C}$, tandis que les semis traités selon des jours courts et chauds alternatifs pour une période complète de dix-neuf semaines n'étaient pas résistants à une température de $-20^{\circ} \mathrm{C}$.

Mots clés: Thuja, durée du jour, photopériode

\section{Introduction}

Approximately 250,000 white cedar (Thuja occidentalis L.) container seedlings are produced in Ontario annually. This species is principally used in southeastern Ontario to reforest old farm lands and wet sites. Although frozen storage of bareroot white cedar seedlings has been studied (Racey et al. 1983), there is little information concerning the induction of frost hardiness in white cedar. Current overwintering strategies for container seedlings of this species are therefore based mainly on cultural experience, rather than on a direct understanding of the dynamics of frost hardening in response to cultural factors. This paper describes the frost hardiness development of shoots of white cedar container seedlings in response to short days and warm or cold temperatures.

\section{Materials and Methods}

Seedlings were grown in Multipot \#1-67 trays as part of the operational crop at the G. Howard Ferguson Forest Station, at Kemptville, Ontario, from sowing in the last week of January, 1985 to May 3, 1985, when 15 trays of seedlings for use in the trial reported here were transported to a heated greenhouse $\left(20-30^{\circ} \mathrm{C}\right.$ day and $15-20^{\circ} \mathrm{C}$ night temperatures) at the Ontario Forest Research Institute in Maple. Beginning June 10th, seedlings were exposed to short days (8:00 am

\footnotetext{
'Ontario Forest Research Institute, Ontario Ministry of Natural Resources, P.O. Box 969, 1235 Queen Street East, Sault Ste. Marie, Ontario P6A 5N5. ${ }^{2}$ Formerly Assistant Superintendent, G. Howard Ferguson Forest Station, Currently Superintendent, St. Williams Nursery, Ontario Ministry of Natural Resources, Southwestern Region RR 1, St. Williams, Ontario NOE 1P0.
}

to $4: 00 \mathrm{pm}$ ) weekdays beginning Monday at $4: 00 \mathrm{pm}$ and ending Friday at 8:00 am, similar to that employed at many tree nurseries using manually operated shade systems. Daylengths on other days of the week were of natural duration. Temperatures were maintained between $20-30^{\circ} \mathrm{C}$ by day and $15-20^{\circ} \mathrm{C}$ by night.

Weekly beginning June 10th, 25 shoot tips were collected for freezing tests. As white cedar seedlings naturally grow with a multiple-leadered stem form and display both juvenile and mature needle forms, all collections for freezing tests were taken from the dominant shoot (i.e. longest, closest to vertical) displaying mature foliage.

Frost hardiness was assessed using freezing tests and the electrical conductivity technique (Colombo et al. 1989). In summary, freezing damage is measured by the change in conductivity in a solution in which shoots are immersed. Shoots which have not been previously frozen or otherwise injured will leach few solutes into solution, causing only a small increase in solution electrical conductivity, since most solutes are retained within the cell. However, when frozen to a damaging temperature, cell membranes lose their semipermeability, allowing leakage of cell solutes (Steponkus 1984). The greater the degree of freezing damage the greater will be the subsequent increase in conductivity of the bathing solution in which previously frozen tissues have been allowed to leach solutes (Levitt 1980).

In this trial, five shoot tips (each $3 \mathrm{~cm}$ long) were placed in each of five test tubes. The tubes were filled with sufficient distilled water to just submerge the shoot tips. After 
24 hours at room temperature, the bathing solution was decanted, and a "control" electrical conductivity measured $\left(\mathrm{EC}_{\mathrm{c}}\right)$ for the supernatant. Tubes containing the shoot tips were equilibrated for 30 minutes at $+2^{\circ} \mathrm{C}$, then frozen at a rate of $5^{\circ} \mathrm{C}$ per hour to $-10^{\circ} \mathrm{C}$. Following thawing of the shoot tips overnight, the previous supernatants were returned to their respective tubes. Twenty four hours later the "frozen" electrical conductivity, $\mathrm{EC}_{\mathrm{f}}$, was measured. Shoots were killed by placing the test tubes containing both shoots and bathing solutions in a $90^{\circ} \mathrm{C}$ oven for 4 hours. Killing allowed the remaining shoot electrolytes to diffuse into solution after a final 24 hours in the original supernatant at room temperature, from which $\mathrm{EC}_{\mathrm{k}}$ was measured. An Index of Injury $\left(I_{t}\right)$ was calculated using a formula derived from that of Flint et al. (1967) as:

$$
I_{\mathrm{t}}=100\left(E C_{\mathrm{f}}-E C_{\mathrm{c}}\right) /\left(E C_{\mathrm{k}}-E C_{\mathrm{c}}\right)
$$

in which a higher Index of Injury indicates greater freezing damage. This formula corrects that previously given by Colombo (1990).

Although the intermittent short day treatment with warm temperatures used in this trial is capable of inducing frost hardiness, cold temperatures have a greater effect in promoting frost hardening (Christersson 1978, Glerum 1985, Greer 1983). Thus the warm intermittent short day conditions provided an environment minimal for hardening. In contrast, cold, continuous short day conditions were expected to promote greater frost hardiness. In order to compare the effects of these two environments on frost hardening, three trays of seedlings were put in a growth chamber providing $10^{\circ} \mathrm{C}$ day and $5^{\circ} \mathrm{C}$ night temperatures and 8 hour daylengths beginning September 9th. On October 21st, five replicates of five shoot tips were collected and frozen to $-20^{\circ} \mathrm{C}$ along with five similar replicates of seedlings which had remained in warm temperatures and intermittent short days throughout the trial.

\section{Results and Discussion}

Height growth ceased after 2 weeks of short day treatment, with no discernable changes in gross morphology of the shoot apex i.e. no budscales. White cedar does not form a bud when entering dormancy, unlike species of the genera Pinus and Picea. Despite the absence of a bud, Index of Injury decreased from $70-80 \%$ to $50-60 \%$ by June 25 (Fig. 1), 2 weeks after short days began and coinciding with the cessation of shoot elongation. Index of Injury stayed near this level from June 24 (week 2) until July 29 (week 7). From week 6 to 14 (September 16), Index of Injury declined linearly in correlation with time $\left(r^{2}=0.905\right)$. The increases in frost hardiness indicated by declining Index of Injury values from week 7 to 14 occurred without exposure to low or freezing temperatures, and may in part have been attributable to the naturally declining photoperiods to which seedlings were exposed over the weekends. The five weeks of low shoot frost hardiness following the end of shoot elongation, followed by a period of steadily increasing frost hardiness, is similar to the pattern of frost hardening in black spruce (Picea mariana (Mill. B.S.P.) (Colombo et al. 1989, Colombo 1990).

While significant increases in frost hardiness occurred under intermittent short days without low temperature exposure, frost hardiness increased further when seedlings received chilling with continuous short days. This was demonstrated on October 21 by comparing Index of Injury

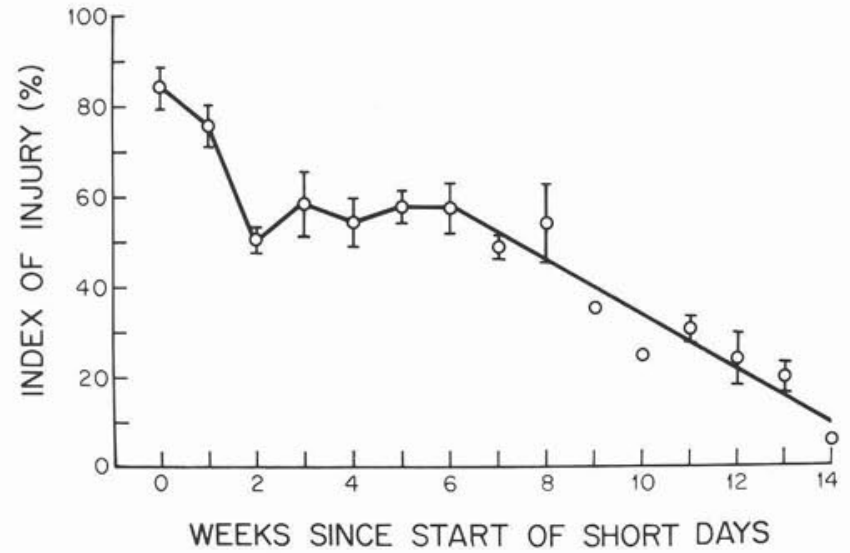

Figure 1. Index of Injury ( \pm standard deviation where it exceeds size of the symbol) following freezing to $-10^{\circ} \mathrm{C}$ of first-year white cedar container seedling shoots under short day, warm temperature conditions. A significant linear correlation exists from weeks 6 to 14 inclusive ( $Y=99.27$ $\left.-5.97 x, r^{2}=0.905^{* *}\right)$.

of warm $\left(20-30^{\circ} \mathrm{C}\right.$ day $/ 15-20^{\circ} \mathrm{C}$ night $)$ versus cold-treated seedlings $\left(10^{\circ} \mathrm{C}\right.$ day $/ 5^{\circ} \mathrm{C}$ night temperatures from September 9 to October 21) following freezing of both groups to $-20^{\circ} \mathrm{C}$. Seedlings that received cool temperature exposure had a significantly lower $(P<0.01)$ Index of Injury $\left(I_{\mathrm{t}}=\right.$ $3.6 \%)$ compared to seedlings receiving only warm temperatures $\left(I_{t}=25.4 \%\right)$. Part of this difference in frost hardiness may also be attributable to the change from intermittent short days in the greenhouse to continuous short days in the growth chamber, or to some other unaccounted for difference between the greenhouse and growth chamber.

By July 15 th, after five weeks of warm short day treatment, the foliage of approximately $25 \%$ of the seedlings had turned brown-green, as opposed to the deeper green colour of the remaining seedlings; the proportion of brown-green seedlings did not increase after July 15 . To determine whether seedling colour was correlated with frost hardiness, separate samples of brown and green seedlings were freeze-tested at $-10^{\circ} \mathrm{C}$ on September 9. Index of Injury values were $20.1 \%$ for green and $12.7 \%$ for brown-green seedlings, a significant difference by the LSD test $(P<0.01)$. The random occurrence of browngreen seedlings in trays suggest that the difference between phenotypes was attributable to genetic as opposed to cultural factors, and could, therefore, potentially be used as a selection criterion in tree improvement programs for white cedar.

Information concerning shoot frost hardiness of white cedar can assist container nursery managers planning hardening regimes for this species. In this trial, shoot frost hardiness increased slightly within 2 weeks of the start of intermittent short days and warm temperatures, and frost hardiness increased linearly with time under warm, short days, with seedlings achieving resistance to damage at $-10^{\circ} \mathrm{C}$ by week 14. Exposure to continuous short days and cold temperatures was necessary for shoots to become hardy to $-20^{\circ} \mathrm{C}$. A proportion of the seedlings developed browngreen foliage colour after 5 weeks of warm, short day treatment, and these seedlings were significantly more frost hardy than seedlings which had dark green foliage.

\section{References}

Christersson, L. 1978. The influence of photoperiod and temperature on the development of frost hardiness in seedlings of Pinus silvestris and Picea abies. Physiol. Plant. 44: 288-294 
Colombo, S.J., C. Glerum and D.P. Webb. 1989. Winter hardening in first-year black spruce (Picea mariana) seedlings. Physiol. Plant. 76: 1-9.

Colombo, S.J. 1990. Bud dormancy status, frost hardiness, shoot moisture content, and readiness of black spruce container seedlings for frozen storage. J. Amer. Soc. Hort. Sci. 115: 302-307.

Flint, H.L., B.R. Boyce and D.J. Beattie. 1967. Index of Injury - A useful expression of freezing injury to plant tissues as determined by the electrolytic method. Can. J. Plant Sci. 47: 229-230.

Glerum, C. 1985. Frost hardiness of coniferous seedlings: Principles and applications. In Proceedings: "Evaluating seedling quality: principles, procedures, and predictive abilities of major tests"'. M.L. Duryea, ed. Oregon State University, Corvallis. pp. 107-123.

Greer, D. 1983. Temperature regulation of the development of frost hardiness in Pinus radiata D. Don. Aust. J. Plant Physiol. 10: $539-547$.

Levitt, J. 1980. Responses of plants to environmental stresses. Vol. I: Chilling, freezing, and high temperature stresses. Academic Press, Toronto, Canada. Second edition. 497 p.

Racey, G.D., C. Glerum and R.E. Hutchison. 1983. Cold and frozen overwinter storage of white cedar. Ontario Ministry of Natural Resources, Nursery Notes No. 90. 6 p.

Steponkus, P.L. 1984. Role of the plasma membrane in freezing injury and cold acclimation. Ann. Rev. Plant Physiol. 35: 543-584.

A Northern ViSion
The School of forestry at Lakehead University invites applications for
a probationary (tenure-track) appointment in one of the following areas;
1. Forest Soils: The incumbent will teach undergraduate courses in
forest soils, forest hydrology and watershed management, give graduate
instruction in forest soils and develop a research program in his/her
speciality. Applicants should hold a Ph.D. in forest soils or a closely
related discipline.
2. Forest management: The incumbent will teach undergraduate and
graduate courses in the application of forest management science and
integrated resources planning in forest resource management and develop
a research program. The applicant should hold a Ph.D. in forestry or
a closely related discipline. A strong asset would be advanced training
in GIS and remote sensing.
The School of Forestry, located at the junction of the Boreal and Great
Lakes St. Lawrence forest regions of northwestern Ontario, offers aca-
demic programs to the Master of Science level. The School has modern
teaching research facilities including The Centre for Application of
Resource Information Systems. It has a close working association with
the University's Centre for Northern Studies and the Centre for Northern
Forest Ecosystems Research operated on campus by the Ontario Ministry
of Natural Resources. It is expected that the appointments will be made
for January 1, 1992. Rank and salary will be commensurate with qualifi-
cations and experience. This position is subject to final budgetary
approval. Applications including curriculum vitae and the names of at
least three references should be sent to: Dr. John Naysmith, Director,
School of Forestry, Lakehead University, 955 Oliver Road, Thunder
Bay, Ontario P7B 5E1.
In accordance with Canadian immigration requirements, priority will
be given to Canadian citizens and permanent residents of Canada. Lake-
head University is committed to employment equity and encourages appli-
cations from women, members of visible minorities, aboriginal peoples,
and persons with disabilities.

